\title{
Acquisition of Materials and Performance of Road Construction Projects in Kenya: A Case of Nairobi County
}

\author{
Msafiri Atibu Seboru \\ Senior Principal Engineer, GIBB International Consulting Engineers \\ Angeline Sabina Mulwa, Lecturer \\ Dorothy Ndunge Kyalo, Senior Lecturer \\ Charles M. Rambo, Associate Professor \\ University of Nairobi, Department of Extra Mural Studies \\ doi: 10.19044/esj.2016.v12n32p221 URL:http://dx.doi.org/10.19044/esj.2016.v12n32p221
}

\begin{abstract}
This study sought to establish the influence of acquisition of materials on performance of road construction projects in Kenya: A case of Nairobi County. The objective of the study was to establish the extent to which acquisition of materials influences performance of road construction projects in Kenya. This study was anchored on the theory of controlling, theory of construction management, and stakeholder theory. The paradigm used was pragmatism and the research approach used was mixed methods. Cross sectional descriptive survey and correlational research design were used. The sample size was 74 senior engineers which comprised 30 senior engineers from consulting engineering firms and 44 senior engineers from construction companies; 74 managing directors which comprised 30 managing directors from consulting engineering firms and 44 managing directors from construction companies. A five point Likert type scale questionnaire was used to collect quantitative data while interview guides were used to collect qualitative data. The statistical tools of analysis that were used for descriptive data were frequencies, percentages, arithmetic mean and standard deviation while the statistical tools that were used for inferential statistics were Pearson's Product Moment Correlation and Linear Regression. The Fisher $(\mathrm{F})$ test was used to test the hypotheses. The results indicated that with $\mathrm{R}^{2}=0.246, \mathrm{~F}(6,40)=2.173$, $\mathrm{p}=0.066>0.05, \mathrm{H}_{1}$ was rejected and it was concluded that acquisition of materials had no statistically significant influence on the performance of road construction projects. However, establishment of quantities of materials required had a statistically significant influence on the performance of road construction projects. The
\end{abstract}


study recommends that organizations that deal with road construction should have appropriate policies on establishment of quantities of materials required.

Keywords: Acquisition of Materials, Performance of Road Construction Projects

\section{Introduction}

The performance of roads in Kenya has not been adequate considering the presence of potholes on the majority of roads. Congestion of traffic has become a serious problem particularly in the urban areas and this has resulted in in huge economic losses in terms of loss of man-hours and wastage of fuel. Acquisition of materials is very important in road construction projects since the materials are incorporated into the works to form the structure of the road. It is therefore important to study the influence of acquisition of materials on the performance of road construction projects in Kenya. Performance of road construction projects is the dependent variable whilst acquisition of materials is the independent variable. The indicators of acquisition of materials are establishment of material types required, establishment of quantities of materials required, testing for quality of materials, procurement of materials, storage of materials, and inventory control. This study is anchored on the theory of controlling, theory of construction management, and stakeholder theory as propagated by Koskela and Howell (2002), Radosavljevic and Bennett (2012), and Phillips, Freeman and Wicks (2003) respectively.

\section{Statement of Problem}

The performance of roads in Kenya has not been adequate considering the presence of potholes on the majority of roads. Traffic congestion has become a serious problem particularly in the urban areas. Gachanja (2015) contends that traffic congestion is one of the key concerns affecting performance of the transport system in Nairobi. In 2008, the economic cost of traffic jams in Nairobi Metropolitan Region was estimated at KShs. 1.9 billion annually, on account of cost of additional time spent on travel due to congestion. The type of traffic congestion being witnessed in Nairobi leads to increased costs, longer travel times, constrained economic productivity, and adverse health and environmental externalities. It has been observed that roads turn into rivers when there is downpour due the failure of the road drainage system. In response to this problem, this study proposed to investigate how the performance of road construction projects is influenced by acquisition of materials. Acquisition of materials is critical in the performance of road construction projects in that materials are incorporated 
into the works to form the structure of the road. The purpose of this study was to investigate the influence of acquisition of materials on performance of road construction projects.

\section{Objective of the Study}

The objective of the study was to establish the extent to which acquisition of materials influences performance of road construction projects in Kenya.

\section{Hypothesis of the Study}

The following hypothesis was tested:

$\mathrm{H}_{0}$ : There is no significant relationship between acquisition of materials and performance of road construction projects.

$\mathrm{H}_{1}$ : There is a significant relationship between acquisition of materials and performance of road construction projects.

\section{Literature Review}

Kumar and Vikranth (2012) contend that construction material planning involves identifying the materials required, estimating quantities, defining specifications, forecasting requirements, locating resources for procurement, getting material samples approved, designing material inventory and developing procurement plan to ensure a smooth flow of materials till the connected construction work are completed at the project site. Ritz (1994) indicates that the basis for construction material resources planning is in the project materials plan. It is important that all the required material needs for the contract are covered in the project materials plan. Transport Research Laboratory (1999) asserts that the geological background of natural road building materials used in all areas of road construction has a profound effect on the engineering performance of these materials. The principal objective in acquiring information about road construction materials is to identify geotechnical materials that are capable of meeting the engineering, economic and environmental requirements of the project.

Ayegba (2013) researched on material management on building construction sites in Nigeria. Findings revealed that, 31\% of respondent organizations procure materials for sites by head office provisions without site requisition, 64\% of respondent organizations procure materials for sites by head office provisions with site requisition and $5 \%$ of respondents organization procure materials for sites through direct purchase by site manager or engineer. A study was carried out by Kasim and Ern (2010) on awareness of information and communication technology (ICT) implementation for materials management in construction projects. Findings revealed that the implementation of ICT in the materials management for 
construction projects in Malaysia was at an early stage. Omojola and Olugboyega (2015) conducted a study on the influence of construction materials supply chain network structures and strategies on project delivery in Nigeria. The findings revealed that the phone and personal interaction were the network systems employed by small contractors to relate with material suppliers. The findings also revealed that suppliers and small contractors were not employing information technology in their supply chain network, and that strategies employed by contractors to select suppliers had a positive influence on cost, quality and schedule of projects.

It is vital to establish the right quantities of materials required for the road construction projects in order to avoid shortages in future which may adversely affect the project. Transport Research Laboratory (1999) asserts that material assessment for road construction projects should address the following issues: the amounts of construction material that have been identified and to what levels of certainty; the amounts of material shortfall in each category, that is, earth-fill, sub-base and road base; recommendations as to what areas should be investigated for materials to cover any shortfall; and planning of further field and laboratory material investigations to counteract the shortfalls. Tanzania National Roads Agency (2003) points out that it is important to make an appropriate allowance for wastage when making resource estimates. In addition to wastage, it is important during field investigations to take into account a considerable loss in case of materials of marginal quality which may be rejected after laboratory testing.

Patel and Vyas (2011) researched on construction materials management on project sites. Findings revealed that poor materials management delayed construction projects and caused increased costs during construction. A study was carried out by Hannure and Kulkarni (2014) in India on traditional materials management. Findings revealed the following problems with manual material management in construction companies: manual errors, increased paper work, difficulty in finding details, difficulty in updating, difficulty in finding the exact location of materials, lengthy procedures, missing documents, and difficulty in communicating information regarding the materials. Muhwezi, Chamuriho and Lema (2012) carried out a study on materials wastes on building construction projects in Uganda. The study revealed that the main causes of waste generation were: changes made to the design while construction was in progress; lack of skills of workers/tradesmen or sub-contractors' skills; purchased products that do not comply with specifications; inappropriate storage facilities at site leading to damage or deterioration; change orders/instructions by supervisors; and severe weather conditions.

Testing of construction materials is very critical so as to ensure that only quality materials are incorporated into the works. Joy (1991) states that 
materials shall be inspected thoroughly from technical angles and tests carried out. Rejected material shall be removed by the seller at his cost. South African National Roads Agency (2011) indicates that the general rule in the construction of cost-effective flexible road pavements is to use the highest quality materials in the top layers of the pavement, where the highest stresses are imposed by the traffic's wheel loads, with a gradual decrease in material quality through the pavement, the poorest quality materials being used deeper in the pavement where the tresses are much reduced. In principle, the highest quality of material that is economically available should always be used. Transport Research Laboratory (1999) contends that materials production from quarries and large borrow-pit sites requires positive management to ensure that the desired quality of materials is maintained. Tanzania National Roads Agency (2003) points out that in the selection of a hard rock quarry, the question of quality is naturally of prime importance. Chudley and Greeno (2008) assert that the majority of materials and components arriving on site will conform to the minimum recommendations of the appropriate standards and therefore the only tests which need be applied are those of checking quantity received against amount stated on the delivery note, ensuring quality is as ordered and a visual inspection to reject damaged or broken goods.

Keng (2011) researched on quality management in construction projects in Malaysia. The following were the findings of the study: total quality management was not a common practice, the international standards organization registration was mainly for marketing purpose, and implementation of quality management was greatly perceived as a mean to fulfill contractual obligations instead of satisfying the needs of clients. A study was carried out by Aichouni, Messaoudene, Al-Ghonamy and Touahmia (2014) on quality management systems in the construction industry in Saudi Arabia. Findings revealed a high degree of misunderstanding of quality management system strategies, tools and techniques in the surveyed construction firms. Research was carried out by Jha and Iyer (2006) on critical factors affecting quality performance in construction projects in India. Findings revealed that the factors that adversely affected the quality performances of projects were: conflict among project participants, hostile socio-economic environment, harsh climatic condition, project manager's lack of knowledge, and aggressive competition during tendering. Adenuga (2013) carried out a study on factors affecting quality in the delivery of public housing projects in Nigeria. The study revealed that the aims and objectives of quality assurance were easily compromised and frequently lost since they relied heavily upon the individual contributions to implementation from each designer, contractor, supplier and sub-contractor. Mane and Patil (2015) researched on quality 
management system at construction projects. Findings revealed that the most important quality tools used at construction site were check lists, fish bone diagram, flow chart, pareto analysis, histogram, check sheets, control charts, scatter diagram and statistical analysis.

Procurement of materials in a timely manner is very important in order to avoid unnecessary delays to the project. Joy (1991) indicates that a construction company should purchase only those materials that cannot be economically made by the company. Patil and Pataskar (2015) contend that the efficient procurement of materials represents a key role in the successful completion of the work. Manavazhi and Adhikari (2002) researched on material and equipment procurement delays in highway projects in Nepal. Findings revealed that the main causes of material and equipment procurement delay were organizational weaknesses, suppliers' defaults, governmental regulations, and transportation delays. Among materials, delays in the supply of aggregates were found to occur most frequently while delays associated with pavers occurred most frequently among equipment. A study was conducted by Zeb, Malik, Nauman, Hanif and Amin (2015) on factors affecting material procurement, supply and management in building projects in Pakistan. Findings revealed that the most significant factors were difficulty in storage of materials on site due to insufficient space, conflict among sub-contractors due to inadequate space available for materials, and hindrance to work progress due to improper stocking of materials.

Alarcon, Rivas and Serpell (1999) carried out a study on improvement of the procurement process in construction projects in Chile. Findings revealed that the main problem of procurement was related to schedule delays and lack of specified quality for the project. Additionally, Kohilambal, Kothai and Priya (2016) researched on material procurement process in the construction industry in India. Findings revealed that the factors affecting the procurement process were temporary demand, increase in price of materials, specialized labour for fixing/installation, disputes between workers, changing sequences in construction activity, nonavailability of resources, revision of design, availability of camp for workers, change in quantities of work, in-time work permissions, problems during execution of work, and safety of workers. Madhavi, Mathew and Sasidharan (2013) carried out a study on material management in construction in India. Findings revealed that material management can be improved by the use of the following: purchase requisition slip, tender quotation form, radio frequency identification, and personal digital assistant.

Storage of materials is critical especially for non-durable materials that deteriorate with time. Storage of adequate quantities of materials can prevent project delays due to temporary shortages of materials in the market. Joy (1991) states that construction materials will carry with them instructions 
for special care in handling and storage. Stored materials will need protection from the weather and burglary. Failure to observe instructions concerning handling, storage and protection can lead to damage an deterioration of materials and delay in construction work. Song, Haas and Caldas (2006) indicate that automated tracking of materials on construction projects has the potential to both improve project performance and enable effortless derivation of project performance indicators. Chudley and Greeno (2008) contend that storage of materials can be defined as the provision of adequate space, protection and control for building materials and components held on site during the construction process.

Kasim (2011) researched on implementation of information and communication technology (ICT) for materials management in construction projects in Malaysia. The findings revealed that spreadsheets and handheld devices were the common ICT tools adopted in the materials management processes. The main barrier was found to be the high cost involvement at the initial stage and in overall implementation of ICT in the materials management processes. A study was carried out by Phu and Cho (2014) on factors affecting material management in building construction projects. Findings revealed that the practices of material management in construction projects needed systematic and effective control. Keitany, Wanyoike and Richu (2014) conducted a study on the role of materials management on organizational performance in Kenya. Findings revealed that there was significant increase in organizational performance as a result of the use of inventory control system. Lenin, Krishmaraj, Prasad and Kumar (2014) carried out a study on improper material management affecting cost in construction projects in India. Findings revealed that the top five major causes of cost overruns were: design issues, market condition, store issues, contractor issues, and external issues.

Inventory control is important in ensuring that the right quantities of materials are on site at any given time. Joy (1991) indicates that the objective of inventory control is to carry such quantity of physical stock as would enable the efficient execution of the construction job at hand, without excess, shortage or idling. The control is exercised by continual review and revision of the minimum-maximum and re-order levels, based on past consumption and future estimate, quantity on order, and physical verification of the stock. Mohan (2015) states that inventory management can be defined as the sum total of those related activities essential for the procurement, storage, sale, disposal or use of material.

Sindhu, Nirmalkumar and Krishnamoorthy (2014) researched on inventory management system in construction industries in India. Findings revealed the following inventory management risks: lack of storage space, problems with decentralized processing, inadequate training practices, 
improper financial support in ordering of materials, and difficulty in delivery of long lead materials. A study was carried out by Arunprakash and Nandhini (2013) on stock management practices in construction companies in India. Findings revealed that all organizations included safety stock in the planning calculation and $40 \%$ of them gave very high importance to stock management. Only $60 \%$ of companies used skilled and trained professionals for stock management. Research was carried out by Ogbo, Onekanma and Ukpere (2014) on the impact of effective inventory control management on organizational performance in Nigeria. Findings revealed that flexibility in inventory control management was an important approach to achieving organizational performance. Organizations benefited from inventory control management by way of easy storage and retrieval of material, improved sales effectiveness and reduced operational cost.

Mogere, Oloko and Okibo (2013) conducted a study on the effect of inventory control systems on operational performance of tea processing firms in Kenya. Findings revealed that the integration of supply chain in vendor managed inventory was crucial in increasing operations efficiency in tea factories. Kairu (2015) carried out a study on the role of strategic inventory management on performance of manufacturing firms in Kenya. From the research findings, the study established that accurate inventory control supported organizational efficiencies in terms of product supply to customers as low inventory caused lost sales while higher inventory impacted negatively on performance of the organization due to tying up of large capital resources, therefore the study concluded that inventory control had a positive influence on performance of manufacturing firms in Kenya. Kitheka and Ondiek (2014) carried out a study on inventory management automation and the performance of supermarkets in Western Kenya. Findings revealed that inventory management automation affected the performance of the supermarkets and that there was a positive linear relationship between inventory management automation and the performance of the supermarkets.

\section{Theoretical Framework}

This study is anchored on the following theories: theory of controlling, theory of construction management, and stakeholder theory.

\section{Theory of Controlling}

The proponents of the theory of controlling were Koskela and Howell (2002). The core process of controlling is divided into two sub-processes: performance reporting and overall change control. Based on the former, corrections are prescribed for the executing processes, and based on the latter, changes are prescribed for the planning processes. Here only 
performance reporting is considered, based on performance baseline and associated corrections to execution. It clearly corresponds to the cybernetic model of management control (thermostat model) that consists of the following elements: there is a standard of performance; performance is measured at the output (or input); and the possible variance between the standard and the measured value is used for correcting the process so that the standard can be reached. The theory of controlling supports this study in the sense that when road construction is being executed, reference must be constantly made to the specifications and programme of works to ensure adherence. Any deviation is corrected to ensure that the project is brought back on track and ensure its timely completion. The dependent variable, performance of road construction projects, is therefore linked to the theory of controlling.

\section{Theory of Construction Management}

The theory of construction management was propagated by Radosavljevic and Bennett (2012). A focus only on project management has limited construction's performance. The development and progress of the construction industry will depend on an understanding of project management to be combined with an equal focus on company management. The theory of construction management begins with the theory that construction management aims to enable construction to be undertaken efficiently and effectively within agreed objectives. The first requirement in achieving the objective of construction management is to select competent teams to undertake all the essential construction actions. Construction team members include: designers, managers, building team, manufacturers, production specialists, and commissioning specialists. The theory of construction management accepts that construction faces inherent difficulties that are unavoidable. The theory is based on the rigorous view that the purpose of construction management is to reduce inherent difficulty. This theory is relevant to this study in that road construction ought to be done efficiently and effectively to ensure completion within time and budget. The dependent variable, performance of road construction projects, is therefore linked to the theory of construction management.

\section{Stakeholder Theory}

The stakeholder theory, according to Phillips, Freeman and Wicks (2003), is a theory of organizational management and ethics. Managing for stakeholders involves attention to more than simply maximizing shareholder wealth. Attention to the interests and well-being of those who can assist or hinder the achievement of the organization's objectives is the central admonition of the theory. Traditionally, according to Takim (2009), the main 
participants in a construction project coalition are the client, the architect and the contractor. The interactions and interrelationships between these participants largely determine the overall performance of a construction project, and have the crucial responsibility for delivering a project to successful completion. Stakeholders are defined as people or groups that have, or believe they have, legitimate claims against the substantive aspects of a project. Stakeholders, according to Chinyio and Olomolaiye (2010), are individuals or groups that benefit from an organization. Further, stakeholders can be harmed or have their rights affected by an organization. Fundamentally, stakeholders affect and are affected by an organization and its activities. Stakeholders can affect an organization's functioning, goals, development and even survival. Stakeholders are beneficial when they help an organization to achieve its goals and they are antagonistic when they oppose the organization's mission. In effect, stakeholders have power to be either a threat or a benefit to an organization.

Austen, Seymour, Brown, Furneaux and McCabe (2008) contend that being able to manage construction stakeholders expectations and concerns is a crucial skill for managers of construction projects, as failure to address these has resulted in countless project failures, primarily because construction stakeholders tend to have the resources and capability to stop construction projects. Successful completion of construction projects is therefore dependant on meeting the expectation of stakeholders. Stakeholders include clients, project managers, designers, subcontractors, suppliers, funding bodies, users, owners, employees and local communities. In this study, government establishments, consulting engineering firms, and construction companies are stakeholders in the construction of roads and therefore the stakeholder theory is pertinent.

\section{Conceptual Framework Independent Variable Dependent Variable}

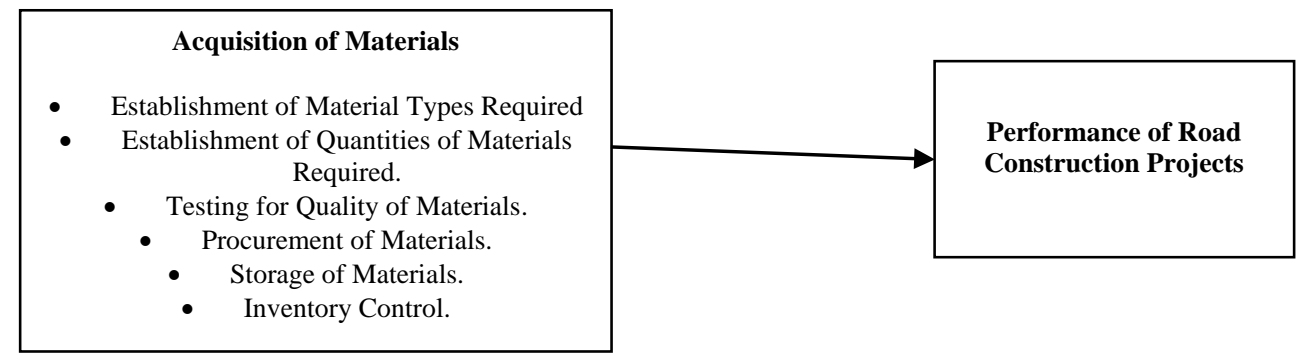

Figure 1: Conceptual Framework for Procurement of Labour and Performance of Road Construction Projects 


\section{Research Methodology}

The research paradigm used in this study was pragmatism. Wambugu, Kyalo, Mbii and Nyonje (2015) state that pragmatists do not see the world as an absolute unity. Mixed method researchers look at many approaches for collecting and analyzing data rather than subscribing to only one way either qualitative or quantitative. Bryman (2006) indicates that research that involves the integration of quantitative and qualitative research has become increasingly common in recent years. Migiro and Magangi (2011) state that mixed methods research encourages researchers to use multiple approaches to collecting and analyzing data within a single study, recognizing the limitations of using a single method. In this study, quantitative data was collected using structured questionnaires whilst qualitative data was collected using interview schedules. Therefore, the paradigm of pragmatism was the most suitable for the study.

The research designs that was used in this study were cross-sectional descriptive survey design and correlational research design. Creswell (2012) indicates that correlational designs provide an opportunity to predict scores and explain the relationship among variables. In correlational research designs, investigators use the correlation statistical test to describe and measure the degree of association (or relationship) between two or more variables or sets of scores. Researchers use inferential statistics to determine whether an expected pattern designated by the theory and hypotheses is actually found in the observations (Nachmias \& Nachmias, 2005; Kothari, 2004; Leedy, 1997; Kombo \& Tromp, 2006; Sekaran, 2003).

The sample sizes for this study were: 30 senior engineers and 30 managing directors in consulting engineering firms, and 44 senior engineers and 44 managing directors in construction companies drawn from the following target population sizes: 30 senior engineers and 30 managing directors in consulting engineering firms, and 44 senior engineers and 44 managing directors in construction companies. The criteria stipulated by Krejcie and Morgan (1970) and Sekaran (2003) were used in the determination of the sample size in this study. The sampling technique adopted in this study was a census of all consulting engineering firms dealing with civil works and belonging to the Association of Consulting Engineers, and also a census of all road contractors falling under Category 'A' at the Ministry of Public Works. Primary data was used in this study. Raw data was gathered directly from the respondents and was used to analyze the relationships that were being investigated in the study. The research instruments that was used for data collection were self-administered structured questionnaires and interview guides. Questionnaires are commonly used to obtain important information about a population (Mugenda \& Mugenda, 2003; Bhattacherjee, 2012; Kothari, 2004; Somekh 
\& Lewin, 2008; Kombo \& Tromp, 2006). In interviews, the researcher can ask key respondents about the facts of a matter as well as their opinions about events (Rubin \& Rubin, 2005; Yin, 2009).

Pilot testing was carried out by administering questionnaires to six senior engineers; three from consulting engineering firms and three from construction companies. Interviews were also conducted on six managing directors; three from consulting engineering firms and three from construction companies. The questionnaire was pretested to a selected sample which was similar to the actual sample used in the study (Kombo \& Tromp, 2006; Bell, 2005; Alreck \& Settle, 1995; Mugenda \& Mugenda, 2003). Testing the validity of research instruments ensures that the instrument measures what it is supposed to measure. In this study, the validity of the research instruments was tested through the content-related method where a panel of experts assessed the content validity. Reliability measures the degree to which a research instrument produces consistent results. In this study, the Cronbach's alpha method was used. A figure of 0.737 for the Cronbach's Alpha coefficient was obtained. According to Bryman (2012), a figure of 0.70 is an acceptable level of internal reliability.

\section{Findings and Discussions}

Questionnaires were administered to 74 senior engineers from organizations dealing with construction of road construction projects out of which 47 were filled and returned forming a response rate of $64 \%$. Saunders, Lewis and Thornhill (2009) state that a response rate of $50 \%$ and above is reasonable for statistical generalization.

\section{Background Information of the Respondents}

The background information of the respondents is shown in Table 1.1.

Table 1.1 Background Information of the Respondents

\begin{tabular}{ccc}
\hline Respondents Profile & Frequency & Percentage \\
\hline Age Bracket (Years) & & \\
$18-20$ & 0 & 0.00 \\
$21-30$ & 3 & 6.38 \\
$31-40$ & 7 & 14.89 \\
$41-50$ & 21 & 44.68 \\
Above 50 & 16 & 34.04 \\
Total & 47 & 100 \\
Gender & & \\
Male & 45 & 95.74 \\
Female & 2 & 4.26 \\
Total & 47 & 100 \\
\hline
\end{tabular}

Highest Education Level

Certificate

0

0.00 


\begin{tabular}{ccc}
\hline Respondents Profile & Frequency & Percentage \\
\hline Diploma & 2 & 4.26 \\
Bachelors & 21 & 44.68 \\
Masters & 24 & 51.06 \\
PhD & 0 & 0 \\
Other & 0 & 0 \\
Total & 47 & 100 \\
\hline Status in Organization & & \\
MD & 1 & 2.13 \\
Director & 4 & 8.51 \\
Manager & 3 & 6.38 \\
Senior Staff & 36 & 76.60 \\
Supervisor & 3 & 6.38 \\
Total & 47 & 100 \\
\hline Work Experience (Years) & & \\
Less than 5 & 0 & 0.00 \\
5 - 10 & 7 & 14.89 \\
11 - 15 & 9 & 19.15 \\
16 - 20 & 9 & 19.15 \\
Above 20 & 22 & 46.81 \\
Total & 47 & 100 \\
\hline (Years) & & \\
Less than 10 & & \\
10 - 20 & 8 & 17.02 \\
Above 20 & 9 & 19.15 \\
Total & 30 & 63.83 \\
\hline Length of Time the Organization has been Operating & 47 & 100 \\
\hline
\end{tabular}

On age, the research findings in Table 1.1 indicate that $6.38 \%$ of the respondents were between $21-30$ years, $14.89 \%$ were between $31-40$ years, $44.68 \%$ were between $41-50$ years, and $34.04 \%$ were above 50 years of age. These findings show that majority of the senior engineers in construction companies and consulting engineering firms were above 40 years and hence experienced in their work. Therefore, the roads constructed by them are expected to perform. On gender, the findings also indicate that $95.74 \%$ of the respondents were male while $4.26 \%$ of the respondents were female. These findings show that the engineering profession is male dominated, despite the constitution encouraging gender balance in various professions.

On level of education, the research findings indicate that $51.06 \%$ of the respondents had Master's degree, $44.68 \%$ had Bachelor's degree and 4.26\% had Diploma. These findings showed that majority of the staff in construction companies and consulting engineering firms have Bachelor's degree and above as highest level of education and are therefore adequately qualified. This implies that the performance of constructed roads is expected to be of quality. On status in organisation, results show that $2.13 \%$ of the respondents were Managing Directors, 8.51\% were Directors, 6.38\% were 
Managers, 76.6\% were Senior Staff, and 6.38\% were Supervisors. Therefore, the vast majority of the respondents were Senior Staff and this implies that roads constructed by them are expected to perform.

On work experience, it was found that $14.89 \%$ of the respondents had 5-10 years work experience, $19.15 \%$ had $11-15$ years, $19.15 \%$ had $16-20$ years, and $46.81 \%$ had above 20 years work experience. Therefore, the majority of the senior engineers in construction companies and consulting engineering firms had over 20 years work experience and this implies that the engineers are expected to utilise their long experience to construct roads that perform. On length of time the organization has been operating, the findings indicate that $17.02 \%$ of the organizations had operated for less than 10 years, $19.15 \%$ had operated for $10-20$ years, and $63.83 \%$ had operated for above 20 years. Therefore, the majority of the organizations had operated for more than 20 years. This implies that they have accumulated years of experience in road construction projects and therefore they are expected to produce quality work output.

\section{Likert-Type Data}

In this study the following Likert Scale was used: 1=To a very little extent; 2=To a little extent; 3=To a moderate extent; 4=To a great extent; and 5=To a very great extent. The following scale was also used: $1=$ Strongly Disagree; 2=Disagree; 3=Neutral; 4=Agree; and 5=Strongly Agree. The following scoring was used: To a very little extent (VLE) $1.0<\mathrm{VLE}<1$.8; To a little extent (LE) 1.8<LE $<2.6$; To a moderate extent (ME) 2.6 $<\mathrm{ME}<3.4$; To a great extent (GE) 3.4 $<\mathrm{GE}<4.2$; and To a very great extent (VGE) 4.2 $<\mathrm{VGE}<5.0$. The following scoring was also used: Strongly Disagree (SD) $1<\mathrm{SD}<1.8$; Disagree (D) $1.8<\mathrm{D}<2.6$; Neutral (N) $2.6<\mathrm{N}<3.4$; Agree (A) $3.4<\mathrm{A}<4.2$; and Strongly Agree (SA) $4.2<\mathrm{SA}<5.0$. The mentioned scales give an equidistance of 0.8 . The above scale was used successfully by Kinyanjui (2014).

\section{Establishment of Materials Types Required and Performance of Road Construction Projects}

Establishment of materials types required was measured by providing respondents with statements rated on a five point Likert scale ranging from: To a very little extent (VLE); To a little extent (LE); To a moderate extent (ME); To a great extent (GE); and To a very great extent (VGE) from which to choose. The findings are presented in Table 1.2. 
Table 1.2: Establishment of Materials Types Required and Performance of Road Construction Projects

\begin{tabular}{|c|c|c|c|c|c|c|c|c|}
\hline Statements & $\begin{array}{l}\text { VLE } \\
\text { F } \\
(\%)\end{array}$ & $\begin{array}{l}\text { LE } \\
\text { F } \\
(\%)\end{array}$ & $\begin{array}{l}\text { ME } \\
\text { F } \\
(\%)\end{array}$ & $\begin{array}{l}\text { GE } \\
\text { F } \\
(\%)\end{array}$ & $\begin{array}{l}\text { VGE } \\
\text { F } \\
(\%)\end{array}$ & Mean & SDV & $\begin{array}{l}\text { Total } \\
\text { F } \\
(\%)\end{array}$ \\
\hline $\begin{array}{l}\text { a) The material types } \\
\text { identified met the } \\
\text { engineering requirements of } \\
\text { the project. }\end{array}$ & $\begin{array}{r}2 \\
(4.3)\end{array}$ & $\begin{array}{c}4 \\
(8.5)\end{array}$ & $\begin{array}{c}6 \\
(12.8)\end{array}$ & $\begin{array}{r}19 \\
(40.4)\end{array}$ & $\begin{array}{r}16 \\
(34.0)\end{array}$ & 3.91 & 1.10 & $\begin{array}{r}47 \\
(100)\end{array}$ \\
\hline $\begin{array}{l}\text { b) The material types } \\
\text { identified met the economic } \\
\text { requirements of the project. }\end{array}$ & $\begin{array}{c}0 \\
(0)\end{array}$ & $\begin{array}{c}1 \\
(2.1)\end{array}$ & $\begin{array}{c}6 \\
(12.8)\end{array}$ & $\begin{array}{r}26 \\
(55.3)\end{array}$ & $\begin{array}{r}14 \\
(29.8)\end{array}$ & 4.13 & 0.71 & $\begin{array}{r}47 \\
(100)\end{array}$ \\
\hline $\begin{array}{l}\text { c) The material types } \\
\text { identified met the } \\
\text { environmental requirements } \\
\text { of the project. }\end{array}$ & $\begin{array}{c}1 \\
(2.1)\end{array}$ & $\begin{array}{r}3 \\
(6.4)\end{array}$ & $\begin{array}{c}7 \\
(14.9)\end{array}$ & $\begin{array}{r}20 \\
(42.6)\end{array}$ & $\begin{array}{r}16 \\
(34.0)\end{array}$ & 4.00 & 0.98 & $\begin{array}{r}47 \\
(100)\end{array}$ \\
\hline Composite for Establishn & of 1 & rials & ges $\mathrm{R}$ & & & & 01 & 0.71 \\
\hline
\end{tabular}

The research findings in Table 1.2 show that out of 47 respondents who participated in the study, 19(40.4\%) of the respondents indicated that to a great extent the material types identified met the engineering requirements of their projects, 26(55.3\%) indicated that to a great extent the material types identified met economic requirements of their projects, and 20(42.6\%) indicated to a great extent the material types identified met the environmental requirements of their projects. The parameter that has the most influence in the performance of road construction projects is that the material types identified met the economic requirements of the project. In road construction projects, it is very important to ensure that identified materials are cost effective in order to complete the project within the planned cost.

The research findings show that to a great extent $(\mathrm{M}=3.91$, $\mathrm{SDV}=1.10$ ) the material types identified met the engineering requirements of the projects and also to a great extent $(\mathrm{M}=4.13, \mathrm{SDV}=0.71)$ the material types identified met the economic requirements of the projects. To a great extent $(M=4.00, \quad S D V=0.98)$ the material types identified met the environmental requirements of the projects. Overall, the surveyed companies to a great extent $(\mathrm{M}=4.01, \mathrm{SDV}=0.71)$ managed to establish the materials types required appropriately. The results imply that establishment of the materials required is very important in the performance of road construction projects since the establishment of appropriate materials can lead to completion of the project within the planned cost and quality standards.

\section{Establishment of Quantities of Materials Required and Performance of Road Construction Projects}

Establishment of quantities of materials required was measured by providing respondents with statements rated on a five point Likert scale 
ranging from: To a very little extent (VLE); To a little extent (LE); To a moderate extent (ME); To a great extent (GE); and To a very great extent (VGE) from which to choose. The findings are presented in Table 1.3.

Table 1.3: Establishment of Quantities of Materials Required and Performance of Road Construction Projects

\begin{tabular}{|c|c|c|c|c|c|c|c|c|}
\hline Statements & $\begin{array}{l}\text { VLE } \\
\text { F } \\
(\%)\end{array}$ & $\begin{array}{l}\text { LE } \\
\text { F } \\
(\%)\end{array}$ & $\begin{array}{l}\text { ME } \\
\text { F } \\
(\%)\end{array}$ & $\begin{array}{l}\text { GE } \\
\text { F } \\
(\%)\end{array}$ & $\begin{array}{l}\text { VGE } \\
\text { F } \\
(\%)\end{array}$ & Mean & SDV & $\begin{array}{l}\text { Total } \\
\text { F } \\
(\%)\end{array}$ \\
\hline $\begin{array}{l}\text { a) The amount of } \\
\text { material shortfall was } \\
\text { established. }\end{array}$ & $\begin{array}{r}15 \\
(31.9)\end{array}$ & $\begin{array}{c}10 \\
(21.3)\end{array}$ & $\begin{array}{r}13 \\
(27.7)\end{array}$ & $\begin{array}{r}6 \\
(12.8)\end{array}$ & $\begin{array}{c}3 \\
(6.4)\end{array}$ & 2.40 & 1.25 & $\begin{array}{r}47 \\
(100)\end{array}$ \\
\hline $\begin{array}{l}\text { b) An allowance was } \\
\text { made for wastage when } \\
\text { making materials } \\
\text { estimates. }\end{array}$ & $\begin{array}{c}0 \\
(0)\end{array}$ & $\begin{array}{c}4 \\
(8.5)\end{array}$ & $\begin{array}{r}19 \\
(40.4)\end{array}$ & $\begin{array}{r}13 \\
(27.7)\end{array}$ & $\begin{array}{r}11 \\
(23.4)\end{array}$ & 3.66 & 0.94 & $\begin{array}{r}47 \\
(100)\end{array}$ \\
\hline $\begin{array}{l}\text { c) An account was taken } \\
\text { of materials of marginal } \\
\text { quality which could be } \\
\text { rejected after laboratory } \\
\text { testing. }\end{array}$ & $\begin{array}{c}3 \\
(6.4)\end{array}$ & $\begin{array}{c}5 \\
(10.6)\end{array}$ & $\begin{array}{r}18 \\
(38.3)\end{array}$ & $\begin{array}{r}10 \\
(21.3)\end{array}$ & $\begin{array}{r}11 \\
(23.4)\end{array}$ & 3.45 & 1.16 & $\begin{array}{r}47 \\
(100)\end{array}$ \\
\hline Required & & & & & & \multicolumn{2}{|c|}{3.17} & 87 \\
\hline
\end{tabular}

The research findings in Table 1.3 show that $15(31.9 \%)$ of the respondents indicated that to a very little extent the amount of material shortfall was established, 19(40.4\%) indicated that to a moderate extent an allowance was made for wastage when making materials estimates, and 18(38.3\%) indicated that to a moderate extent an account was taken of materials of marginal quality which could be rejected after laboratory testing. The parameter that has the most influence in the performance of road construction projects is that an allowance was made for wastage when making materials estimates. In road construction projects, it is very important to make an allowance for wastage of materials in order to avoid material shortages in future which in turn could lead to project delays.

The research findings show that to a little extent $(\mathrm{M}=2.40$, $\mathrm{SDV}=1.25$ ) the amount of material shortfall was established and to a great extent $(M=3.66, S D V=0.94)$ an allowance was made for wastage when making materials estimates. To a great extent $(\mathrm{M}=3.45, \mathrm{SDV}=1.16)$ an account was taken of materials of marginal quality which could be rejected after laboratory testing. Overall, the surveyed companies to a moderate extent ( $M=3.17$, SDV=0.87) managed to establish the quantities of materials required appropriately. The results imply that establishment of quantities of materials required is very important in the performance of road construction projects since the establishment of accurate quantities of materials can avoid future shortages of materials and avoid time overruns. 


\section{Testing for Quality of Materials and Performance of Road Construction Projects}

Testing for quality of materials was measured by providing respondents with statements rated on a five point Likert scale ranging from Strongly Disagree (SD); Disagree (D); Neutral (N); Agree (A); and Strongly Agree (SA) from which to choose. The findings are presented in Table 1.4.

Table 1.4: Testing for Quality of Materials and Performance of Road Construction Projects

\begin{tabular}{|c|c|c|c|c|c|c|c|c|}
\hline Statements & $\begin{array}{c}\text { SD } \\
\text { F } \\
(\%)\end{array}$ & $\begin{array}{l}\mathrm{D} \\
\mathrm{F} \\
(\%)\end{array}$ & $\begin{array}{l}\mathrm{N} \\
\mathrm{F} \\
(\%)\end{array}$ & $\begin{array}{c}\mathrm{A} \\
\mathrm{F} \\
(\%)\end{array}$ & $\begin{array}{l}\text { SA } \\
\text { F } \\
(\%)\end{array}$ & Mean & SDV & $\begin{array}{l}\text { Total } \\
\text { F } \\
(\%)\end{array}$ \\
\hline $\begin{array}{c}\text { a) A laboratory was set up } \\
\text { on site for testing of } \\
\text { materials. }\end{array}$ & $\begin{array}{c}2 \\
(4.3)\end{array}$ & $\begin{array}{c}6 \\
(12.8)\end{array}$ & $\begin{array}{r}2 \\
(4.3)\end{array}$ & $\begin{array}{c}22 \\
(46.8)\end{array}$ & $\begin{array}{c}15 \\
(31.9)\end{array}$ & 3.89 & 1.13 & $\begin{array}{r}47 \\
(100)\end{array}$ \\
\hline $\begin{array}{l}\text { b) Materials were taken } \\
\text { for testing to laboratories } \\
\text { away from the site. }\end{array}$ & $\begin{array}{c}11 \\
(23.4)\end{array}$ & $\begin{array}{c}23 \\
(48.9)\end{array}$ & $\begin{array}{r}3 \\
(6.4)\end{array}$ & $\begin{array}{c}3 \\
(6.4)\end{array}$ & $\begin{array}{c}7 \\
(14.9)\end{array}$ & 2.40 & 1.33 & $\begin{array}{r}47 \\
(100)\end{array}$ \\
\hline $\begin{array}{l}\text { c) Rejected materials were } \\
\text { removed from site. }\end{array}$ & $\begin{array}{c}1 \\
(2.1)\end{array}$ & $\begin{array}{c}5 \\
(10.6)\end{array}$ & $\begin{array}{c}2 \\
(4.3)\end{array}$ & $\begin{array}{c}28 \\
(59.6)\end{array}$ & $\begin{array}{c}11 \\
(23.4)\end{array}$ & 3.91 & 0.95 & $\begin{array}{r}47 \\
(100)\end{array}$ \\
\hline
\end{tabular}

The research findings in Table 1.4 show that 22(46.8\%) of the respondents agreed that a laboratory was set up on site for testing of materials, 23(48.9\%) disagreed that materials were taken for testing to laboratories away from the site, and 28(59.6\%) agreed that rejected materials were removed from site. The parameter that has the most influence in the performance of road construction projects is that rejected materials were removed from the site. In road construction projects, it is very important to ensure that rejected materials are removed from site in order to remove the risk of incorporating the rejected materials into the works thereby compromising the quality standards.

The research findings show that respondents agreed $(M=3.89$, $\mathrm{SDV}=1.13$ ) that a laboratory was set up on site for testing of materials. They disagreed $(M=2.40, S D V=1.33)$ that materials were taken for testing to laboratories away from the site. The respondents agreed $(M=3.91$, $\mathrm{SDV}=0.95)$ that rejected materials were removed from site. Overall, the surveyed companies agreed $(\mathrm{M}=3.40, \mathrm{SDV}=0.49)$ on the importance of testing for quality of materials. The results imply that testing for quality of materials is very important in the performance of road construction projects since the use of high quality materials will lead to the delivery of high quality works. 


\section{Procurement of Materials and Performance of Road Construction Projects}

Procurement of materials was measured by providing respondents with statements rated on a five point Likert scale ranging from Strongly Disagree (SD); Disagree (D); Neutral (N); Agree (A); and Strongly Agree (SA) from which to choose. The findings are presented in Table 1.5.

Table 1.5: Procurement of Materials and Performance of Road Construction Projects

\begin{tabular}{|c|c|c|c|c|c|c|c|c|}
\hline Statements & $\begin{array}{c}\text { SD } \\
\text { F } \\
(\%) \\
\end{array}$ & $\begin{array}{l}\mathrm{D} \\
\mathrm{F} \\
(\%)\end{array}$ & $\begin{array}{c}\mathrm{N} \\
\mathrm{F} \\
(\%)\end{array}$ & $\begin{array}{c}\text { A } \\
\text { F } \\
(\%)\end{array}$ & $\begin{array}{c}\text { SA } \\
\text { F } \\
(\%) \\
\end{array}$ & Mean & SDV & $\begin{array}{l}\text { Total } \\
\text { F } \\
(\%)\end{array}$ \\
\hline $\begin{array}{l}\text { a) Our company allocated } \\
\text { resources for procurement of } \\
\text { materials. }\end{array}$ & $\begin{array}{r}1 \\
(2.1)\end{array}$ & $\begin{array}{r}3 \\
(6.4)\end{array}$ & $\begin{array}{c}7 \\
(14.9)\end{array}$ & $\begin{array}{r}28 \\
(59.6)\end{array}$ & $\begin{array}{c}8 \\
(17.0)\end{array}$ & 3.83 & 0.87 & $\begin{array}{r}47 \\
(100)\end{array}$ \\
\hline $\begin{array}{l}\text { b) Our company developed a } \\
\text { procurement plan. }\end{array}$ & $\begin{array}{r}2 \\
(4.3)\end{array}$ & $\begin{array}{r}3 \\
(6.4)\end{array}$ & $\begin{array}{c}6 \\
(12.8)\end{array}$ & $\begin{array}{r}24 \\
(51.1)\end{array}$ & $\begin{array}{c}12 \\
(25.5)\end{array}$ & 3.87 & 1.01 & $\begin{array}{r}47 \\
(100)\end{array}$ \\
\hline $\begin{array}{l}\text { c) Our company purchased the } \\
\text { right quantity of materials to } \\
\text { avoid wastage, shortage or } \\
\text { emergency purchases. }\end{array}$ & $\begin{array}{r}2 \\
(4.3)\end{array}$ & $\begin{array}{r}3 \\
(6.4)\end{array}$ & $\begin{array}{c}6 \\
(12.8)\end{array}$ & $\begin{array}{c}22 \\
(46.8)\end{array}$ & $\begin{array}{c}14 \\
(29.8)\end{array}$ & 3.91 & 1.04 & $\begin{array}{r}47 \\
(100)\end{array}$ \\
\hline Composite for Procuremen & $M$ & & & & & & 87 & \\
\hline
\end{tabular}

The research findings in Table 1.5 show that 28(59.6\%) of the respondents agreed that their companies allocated resources for procurement of materials, 24(51.1\%) agreed that their companies developed procurement plans, and 22(46.8\%) agreed that their companies purchased the right quantities of materials to avoid wastage, shortage or emergency purchases. The parameter that has the most influence in the performance of road construction projects is that the company purchased the right quantity of materials to avoid wastage, shortage or emergency purchases. In road construction projects, it is very important to ensure that the right quantities of materials are purchased in order to avoid wastage, shortage and emergency purchases which can lead to time and cost overruns.

The research findings show that respondents agreed $(M=3.83$, $\mathrm{SDV}=0.87$ ) that their companies allocated resources for procurement of materials. They also agreed $(\mathrm{M}=3.87, \mathrm{SDV}=1.01)$ that their companies developed a procurement plan. The respondents agreed $(\mathrm{M}=3.91$, $\mathrm{SDV}=1.04$ ) that their companies purchased the right quantities of materials to avoid wastage, shortage or emergency purchases. Overall, the surveyed companies agreed $(\mathrm{M}=3.87, \mathrm{SDV}=0.80)$ on the importance of procurement of materials. The results imply that procurement of materials is very important in the performance of road construction projects because if the procurement is not done properly, it can lead to time and cost overruns. 


\section{Storage of Materials and Performance of Road Construction Projects}

Storage of materials was measured by providing respondents with statements rated on a five point Likert scale ranging from Strongly Disagree (SD); Disagree (D); Neutral (N); Agree (A); and Strongly Agree (SA) from which to choose. The findings are presented in Table 1.6.

Table 1.6: Storage of Materials and Performance of Road Construction Projects

\begin{tabular}{|c|c|c|c|c|c|c|c|c|}
\hline Statements & $\begin{array}{c}\text { SD } \\
\text { F } \\
(\%)\end{array}$ & $\begin{array}{c}\mathrm{D} \\
\mathrm{F} \\
(\%)\end{array}$ & $\begin{array}{c}\mathrm{N} \\
\mathrm{F} \\
(\%)\end{array}$ & $\begin{array}{c}\text { A } \\
F \\
(\%)\end{array}$ & $\begin{array}{c}\text { SA } \\
\text { F } \\
(\%)\end{array}$ & Mean & SDV & $\begin{array}{c}\text { Total } \\
\text { F } \\
(\%)\end{array}$ \\
\hline $\begin{array}{l}\text { a) There was efficient store- } \\
\text { keeping at the sites. }\end{array}$ & $\begin{array}{r}3 \\
(6.4)\end{array}$ & $\begin{array}{r}2 \\
(4.3)\end{array}$ & $\begin{array}{r}5 \\
(10.6)\end{array}$ & $\begin{array}{c}24 \\
(51.1)\end{array}$ & $\begin{array}{c}13 \\
(27.7)\end{array}$ & 3.89 & 1.07 & $\begin{array}{r}47 \\
(100)\end{array}$ \\
\hline $\begin{array}{l}\text { b) There was adequate } \\
\text { storage space at the sites. }\end{array}$ & $\begin{array}{c}2 \\
(4.3)\end{array}$ & $\begin{array}{r}3 \\
(6.4)\end{array}$ & $\begin{array}{c}5 \\
(10.6)\end{array}$ & $\begin{array}{c}19 \\
(40.4)\end{array}$ & $\begin{array}{c}18 \\
(38.3)\end{array}$ & 4.02 & 1.07 & $\begin{array}{r}47 \\
(100)\end{array}$ \\
\hline $\begin{array}{l}\text { c) Double handling of } \\
\text { materials was avoided. }\end{array}$ & $\begin{array}{c}1 \\
(2.1)\end{array}$ & $\begin{array}{r}4 \\
(8.5)\end{array}$ & $\begin{array}{c}10 \\
(21.3)\end{array}$ & $\begin{array}{c}22 \\
(46.8)\end{array}$ & $\begin{array}{c}10 \\
(21.3)\end{array}$ & 3.77 & 0.96 & $\begin{array}{r}47 \\
(100)\end{array}$ \\
\hline $\begin{array}{l}\text { d) There was proper stocking } \\
\text { of materials at the sites. }\end{array}$ & $\begin{array}{c}1 \\
(2.1)\end{array}$ & $\begin{array}{r}3 \\
(6.4)\end{array}$ & $\begin{array}{c}4 \\
(8.5)\end{array}$ & $\begin{array}{c}23 \\
(48.9)\end{array}$ & $\begin{array}{c}16 \\
(34.0)\end{array}$ & 4.06 & 0.94 & $\begin{array}{r}47 \\
(100)\end{array}$ \\
\hline
\end{tabular}

The research findings in Table 1.6 show that 24(51.1\%) of the respondents agreed that there was efficient store-keeping at the sites, $19(40.4 \%)$ agreed that there was adequate storage space at the sites, 22(46.8\%) agreed that double handling of materials was avoided, and 23(48.9\%) agreed that there was proper stocking of materials at the sites, The parameter that has the most influence in the performance of road construction projects is that there was proper stocking of materials at the sites. In road construction projects, it is very important to ensure that there are adequate stockpiles of materials on site in order to avoid shortages which can lead to time overruns.

The research findings show that respondents agreed $(M=3.89$, $\mathrm{SDV}=1.07)$ that there was efficient store-keeping at the sites. They also agreed $(\mathrm{M}=4.02, \mathrm{SDV}=1.07)$ that there was adequate storage space at the sites. The respondents agreed $(\mathrm{M}=3.77, \mathrm{SDV}=0.96)$ that double handling of materials was avoided. They also agreed $(\mathrm{M}=4.06, \mathrm{SDV}=0.94)$ that there was proper stocking of materials at the sites. Overall, the surveyed companies agreed $(\mathrm{M}=3.94, \mathrm{SDV}=0.78)$ on the importance of storage of materials. The results imply that storage of materials is very important in the performance of road construction projects because lack of storage can result in shortage of materials on site which in turn can lead to time overruns. 


\section{Inventory Control and Performance of Road Construction Projects}

Inventory control was measured by providing respondents with statements rated on a five point Likert scale ranging from Strongly Disagree (SD); Disagree (D); Neutral (N); Agree (A); and Strongly Agree (SA) from which to choose. The findings are presented in Table 1.7.

Table 1.7: Inventory Control and Performance of Road Construction Projects

\begin{tabular}{|c|c|c|c|c|c|c|c|c|}
\hline Statements & $\begin{array}{l}\text { SD } \\
\text { F } \\
(\%)\end{array}$ & $\begin{array}{l}\mathrm{D} \\
\mathrm{F} \\
(\%)\end{array}$ & $\begin{array}{l}\mathrm{N} \\
\mathrm{F} \\
(\%)\end{array}$ & $\begin{array}{c}\text { A } \\
F \\
(\%) \\
\end{array}$ & $\begin{array}{l}\text { SA } \\
\text { F } \\
(\%)\end{array}$ & Mean & SDV & $\begin{array}{c}\text { Total } \\
\text { F } \\
(\%)\end{array}$ \\
\hline $\begin{array}{l}\text { a) Optimum quantities of } \\
\text { materials were } \\
\text { maintained at all times. }\end{array}$ & $\begin{array}{c}1 \\
(2.1)\end{array}$ & $\begin{array}{c}5 \\
(10.6)\end{array}$ & $\begin{array}{c}7 \\
(14.9)\end{array}$ & $\begin{array}{c}20 \\
(42.6)\end{array}$ & $\begin{array}{c}14 \\
(29.8)\end{array}$ & 3.87 & 1.03 & $\begin{array}{r}47 \\
(100)\end{array}$ \\
\hline $\begin{array}{l}\text { b) Difficulty of } \\
\text { delivering long lead } \\
\text { materials was avoided. }\end{array}$ & $\begin{array}{c}0 \\
(0)\end{array}$ & $\begin{array}{c}3 \\
(6.4)\end{array}$ & $\begin{array}{c}12 \\
(25.5)\end{array}$ & $\begin{array}{c}23 \\
(48.9)\end{array}$ & $\begin{array}{c}9 \\
(19.1)\end{array}$ & 3.81 & 0.82 & $\begin{array}{r}47 \\
(100)\end{array}$ \\
\hline $\begin{array}{l}\text { c) There was proper } \\
\text { financial support during } \\
\text { ordering of materials. }\end{array}$ & $\begin{array}{c}5 \\
(10.6)\end{array}$ & $\begin{array}{c}2 \\
(4.3)\end{array}$ & $\begin{array}{c}6 \\
(12.8)\end{array}$ & $\begin{array}{c}17 \\
(36.2)\end{array}$ & $\begin{array}{c}17 \\
(36.2)\end{array}$ & 3.83 & 1.27 & $\begin{array}{r}47 \\
(100)\end{array}$ \\
\hline $\begin{array}{l}\text { d) Retrieval of materials } \\
\text { from storage was easy. }\end{array}$ & $\begin{array}{c}0 \\
(0)\end{array}$ & $\begin{array}{c}1 \\
(2.1)\end{array}$ & $\begin{array}{c}6 \\
(12.8)\end{array}$ & $\begin{array}{c}25 \\
(53.2)\end{array}$ & $\begin{array}{c}15 \\
(31.9)\end{array}$ & 4.15 & 0.72 & $\begin{array}{r}47 \\
(100)\end{array}$ \\
\hline Composite for Invent & Contr & & & & & & \multicolumn{2}{|l|}{3.91} \\
\hline
\end{tabular}

The research findings in Table 1.7 show that 20(42.6\%) of the respondents agreed that optimum quantities of materials were maintained at all times, 23(48.9\%) agreed that difficulty of delivering long lead materials was avoided, 17(36.2\%) agreed that there was proper financial support during ordering of materials, and 25(53.2\%) agreed that retrieval of materials from storage was easy. The parameter that has the most influence in the performance of road construction projects is that retrieval of materials from storage was easy. In road construction projects, it is very important to ensure that materials are easily retrieved from storage in order to avoid delays to the project.

The research findings show that respondents agreed $(\mathrm{M}=3.87$, $\mathrm{SDV}=1.03$ ) that optimum quantities of materials were maintained at all times. They also agreed $(\mathrm{M}=3.81, \mathrm{SDV}=0.82)$ that difficulty of delivering long lead materials was avoided. The respondents agreed $(M=3.83$, $\mathrm{SDV}=1.27$ ) that there was proper financial support during ordering of materials. They also agreed $(\mathrm{M}=4.15, \mathrm{SDV}=0.72)$ that retrieval of materials from storage was easy. Overall, the surveyed companies agreed ( $M=3.91$, $\mathrm{SDV}=0.79$ ) on the importance of inventory control. The results imply that inventory control is very important in the performance of road construction projects because poor inventory control can lead to delays in the project. 


\section{Overall Descriptive Analysis on Acquisition of Materials}

The overall findings on the extent to which organizations utilize acquisition of materials are shown in Table 1.8. The following have been considered under acquisition of materials: establishment of material types required, establishment of quantities of materials required, testing for quality of materials, procurement of materials, storage of materials, and inventory control.

Table 1.8: Means and Standard Deviations for Acquisition of Materials

\begin{tabular}{|c|c|c|c|}
\hline Components of Acquisition of Materials & $\mathrm{n}$ & Mean & SDV \\
\hline a) Establishment of Material Types Required & 47 & 4.01 & 0.71 \\
\hline b) Establishment of Quantities of Materials Required. & 47 & 3.17 & 0.87 \\
\hline c) Testing for Quality of Materials. & 47 & 3.40 & 0.49 \\
\hline d) Procurement of Materials. & 47 & 3.87 & 0.80 \\
\hline e) Storage of Materials. & 47 & 3.94 & 0.78 \\
\hline f) Inventory Control. & 47 & 3.91 & 0.79 \\
\hline Overall Acquisition of Materials & & 3.72 & 0.58 \\
\hline
\end{tabular}

The research findings in Table 1.8 show that the overall mean for acquisition of materials was 3.72 and the standard deviation was 0.58 . The most dominant indicator was establishment of material types required $(\mathrm{M}=4.01, \quad \mathrm{SDV}=0.71)$, followed by storage of materials $(\mathrm{M}=3.94$, SDV=0.78), inventory control $(\mathrm{M}=3.91, \mathrm{SDV}=0.79)$, procurement of materials $(\mathrm{M}=3.87, \mathrm{SDV}=0.80)$, testing for quality of materials $(\mathrm{M}=3.40$, $\mathrm{SDV}=0.49)$, establishment of quantities of materials required $(\mathrm{M}=3.17$, $\mathrm{SDV}=0.87$ ), in that order. This implies that establishment of material types required is very important in performance of road construction projects because appropriate materials are established which can lead to completion of the project within the planned cost and quality standards.

Results of interviews held with managing directors of construction companies and consulting engineering firms indicate that acquisition of materials influences performance of road construction projects to a great extent.

\section{Correlational Analysis of Acquisition of Materials and Performance of Road Construction Projects}

Correlational analysis using Pearson's Product Moment technique was done to determine the relationship between indicators of acquisition of materials and performance of road construction projects. It was meant to identify the strength and direction of the association between the indicators of acquisition of materials and performance of road construction projects. The results are summarized in Table 1.9. 
Table 1.9: Correlation Matrix for Acquisition of Materials and Performance of Road Construction Projects

\begin{tabular}{|c|c|c|c|c|c|c|c|c|}
\hline & & $\begin{array}{l}\text { Establishm } \\
\text { ent of } \\
\text { Material } \\
\text { Types } \\
\text { Required }\end{array}$ & $\begin{array}{c}\text { Establish } \\
\text { ment of } \\
\text { Quantities } \\
\text { of } \\
\text { Materials } \\
\text { Required }\end{array}$ & $\begin{array}{l}\text { Testin } \\
\text { g for } \\
\text { Qualit } \\
\text { y of } \\
\text { Materi } \\
\text { als } \\
\end{array}$ & $\begin{array}{c}\text { Procure } \\
\text { ment of } \\
\text { Material } \\
\text { s }\end{array}$ & $\begin{array}{c}\text { Storag } \\
\text { e of } \\
\text { Materi } \\
\text { als }\end{array}$ & $\begin{array}{c}\text { Invent } \\
\text { ory } \\
\text { Contro } \\
1\end{array}$ & $\begin{array}{l}\text { Acquisit } \\
\text { ion of } \\
\text { Material } \\
\text { s }\end{array}$ \\
\hline \multirow[t]{4}{*}{$\begin{array}{l}\text { Performa } \\
\text { nce of } \\
\text { Road } \\
\text { Construc } \\
\text { tion } \\
\text { Projects }\end{array}$} & $\begin{array}{l}\text { Pearson } \\
\text { Correlati } \\
\text { on }\end{array}$ & .063 & $.373 * *$ & .030 & .005 & .070 & -.053 & .115 \\
\hline & $\begin{array}{l}\text { Sig. (2- } \\
\text { tailed) }\end{array}$ & .675 & .010 & .839 & .973 & .639 & .723 & .441 \\
\hline & $\mathrm{N}$ & 47 & 47 & 47 & 47 & 47 & 47 & 47 \\
\hline & & & $\begin{array}{l}\text { **.Correlc } \\
* \text { *.Correla }\end{array}$ & $\begin{array}{l}\text { is sig } \\
\text { is sigr }\end{array}$ & $\begin{array}{l}\text { ant at th } \\
\text { ant at the }\end{array}$ & $\begin{array}{l}.01 \text { leve } \\
.05 \text { leve }\end{array}$ & $\begin{array}{l}\text { 2-tailed } \\
\text { 2-tailed) }\end{array}$ & \\
\hline
\end{tabular}

The correlation results in Table 1.9 indicate that establishment of quantities of materials required had a weak and statistically significant relationship with performance of road construction projects $(r=.373$, pvalue $<0.01$ ). The other indicators, namely, establishment of material types required, testing for quality of materials, procurement of materials, storage of materials, inventory control, and acquisition of materials did not have a significant relationship with performance of road construction projects.

\section{Inferential Analysis of Influence of Acquisition of Materials on Performance of Road Construction Projects}

The following hypothesis was tested using simple regression model to satisfy the objective.

$\mathrm{H}_{0}$ : There is no significant relationship between acquisition of materials and performance of road construction projects.

$\mathrm{H}_{1}$ : There is a significant relationship between acquisition of materials and performance of road construction projects.

The null hypothesis was tested using the following linear regression model:

Where:

$$
y=\mathrm{a}+\mathrm{b}_{3} X_{3}+\mathrm{e}
$$

$y$ - Performance of Road Construction Projects

a - Constant Term

$\mathrm{b}_{3}$ - Regression Coefficient

$X_{3}-$ Acquisition of Materials

e - Error Term

The results are presented in Table 1.10. 
Table 1.10: Regression Results for Influence of Acquisition of Materials on Performance of Road Construction Projects

\begin{tabular}{ccccccc}
\hline \multicolumn{1}{c}{} & \multicolumn{7}{c}{ Unstandardized Coefficients } & \multicolumn{2}{c}{$\begin{array}{c}\text { Standardized } \\
\text { Coefficients }\end{array}$} \\
& Model & $\mathrm{B}$ & Std. Error & Beta & $\mathrm{t}$ & Sig. \\
\hline \multirow{2}{*}{1} & (Constant) & 3.117 & .466 & & 6.682 & .000 \\
& EstMatTypeTotal & -.059 & .135 & -.101 & -.435 & .666 \\
& EstQuantMatTotal & .256 & .081 & .535 & 3.169 & .003 \\
& TestQualMatTotal & -.197 & .148 & -.231 & -1.331 & .191 \\
& ProcMatTotal & .018 & .132 & .035 & .136 & .892 \\
& StorageMatTotal & .232 & .174 & .436 & 1.328 & .192 \\
& InventControlTotal & -.287 & .164 & -.544 & -1.748 & .088
\end{tabular}

Predictors: (Constant), Establishment of Material Types Required, Establishment of Quantities of Materials Required, Testing for Quality of Materials, Procurement of Materials, Storage of Materials, Inventory Control

Dependent Variable: Performance of Road Construction Projects

$$
\mathbf{R}=.496
$$

$\mathrm{R}$ Square $=.246$

$F(6,40)=2.173$ at level of significance $p=0.066>0.05$

The study findings in Table 1.10 show that $r$ is equal to 0.496 , indicating that acquisition of materials has a moderate influence on performance of road construction projects. The value of $\mathrm{R}$ squared is 0.246 , indicating that acquisition of materials explains $24.6 \%$ of the variation in the performance of road construction projects. The Beta $(\beta)$ coefficients for the indicators are as follows: establishment of material types required is -0.101 ; establishment of quantities of materials required is 0.535; testing for quality of materials is -0.231 ; procurement of materials is 0.035 ; storage of materials is 0.436 ; and inventory control is -0.544 . The $\beta$ values imply that one unit change in performance of road construction projects is associated with $10.1 \%$ change in establishment of material types required, 53.5\% change in establishment of quantities of materials required, $23.1 \%$ change in testing for quality of materials, $3.5 \%$ change in procurement of materials, $43.6 \%$ change in storage of materials, and $54.4 \%$ change in inventory control.

The results indicate that establishment of materials types required had no statistically significant influence on the performance of road construction projects $(\beta=-0.101, t=-0.435, p=0.666>0.05)$. Establishment of quantities of materials required had a statistically significant influence on the performance of road construction projects $(\beta=0.535, \mathrm{t}=3.169, \mathrm{p}=0.003<0.05)$. Testing for quality of materials had no statistically significant influence on the performance of road construction projects $(\beta=-0.231, t=-1.331$, $\mathrm{p}=0.191>0.05$ ). Procurement of materials had no statistically significant influence on the performance of road construction projects $(\beta=0.035$, $\mathrm{t}=0.136, \mathrm{p}=0.892>0.05$ ). Storage of materials had no statistically significant 
influence on the performance of road construction projects $(\beta=0.436$, $\mathrm{t}=1.328$, $\mathrm{p}=0.192>0.05)$. Inventory control had no statistically significant influence on the performance of road construction projects $(\beta=-0.544, t=-$ 1.748, $\mathrm{p}=0.088>0.05)$.

The overall F-statistic was $(6,40)=2.173$ with $\mathrm{p}=0.066>0.05$ suggesting that there was no statistically significant relationship between acquisition of materials and performance of road construction projects. Based on the research findings, we do not reject the null hypothesis which stated that there is no significant relationship between acquisition of materials and performance of road construction projects and conclude that acquisition of materials has no statistically significant influence on the performance of road construction projects.

Using the statistical findings, the regression model can be substituted as follows:

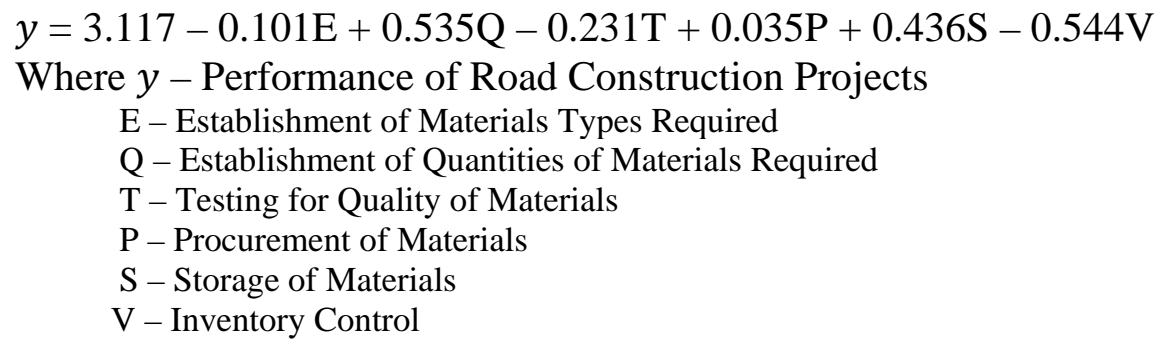

\section{Conclusion and Recommendations}

This section presents the conclusions made in the study in the context of the findings. The conclusions are made in line with the objective and hypothesis. The research objective was to determine the extent to which acquisition of materials influences performance of road construction projects in Kenya. The indicators for acquisition of materials were establishment of materials types required, establishment of quantities of materials required, testing for quality of materials, procurement of materials, storage of materials, and inventory control. The most dominant indicator was establishment of material types required, followed by storage of materials, inventory control, procurement of materials, testing for quality of materials, establishment of quantities of materials required, in that order. The results indicate that establishment of materials types required had no statistically significant influence on the performance of road construction projects. Establishment of quantities of materials required had a statistically significant influence on the performance of road construction projects. Testing for quality of materials had no statistically significant influence on the performance of road construction projects. Procurement of materials had no statistically significant influence on the performance of road construction projects. Storage of materials had no statistically significant influence on the 
performance of road construction projects. Inventory control had no statistically significant influence on the performance of road construction projects. Overall, there was no statistically significant relationship between acquisition of materials and performance of road construction projects.

This study has revealed that establishment of quantities of materials required has an influence on the performance of road construction projects. It is recommended that organizations that deal with road construction should have appropriate policies on establishment of quantities of materials required so as to enhance performance of road construction projects.

\section{References:}

1. Adenuga, O. A. (2013). Factors Affecting Quality in the Delivery of Public Housing Projects in Lagos State, Nigeria. International Journal of Engineering and Technology, 3(3), 332-344. Retrieved from

2. www.unilag.edu.ng/opendoc.php?sno=24071\&amp;doctype=pdf...Fa ctors

3. Aichouni, M., Messaoudene, N. A., Al-Ghonamy, A., \& Touahmia, M. (2014). An Empirical Study of Quality Management Systems in the Saudi Construction Industry. International Journal of Construction Management, 14(3), 181-190. doi: 10.1080/15623599.2014.922724

4. Alarcon, L. F., Rivas, R., \& Serpell, A. (1999). Evaluation and Improvement of the Procurement Process in Construction Projects. Proceedings of IGLC-7, University of California, Berkeley, CA, USA, 219-230. Retrieved from

5. http://www.ce.berkeley.edu/ tommelein/IGLC-

7/PDF/Alarcon\&Rivas\&Serpell.pdf_Alreck, P. L., \& Settle, R. B. (1995). The Survey Research Handbook (2nd ed.). Boston: Irwin McGraw-Hill.

6. Arunprakash, N., \& Nandhini, N. (2013). Study on Stock Management Practices in Construction Companies. Research Journal of Management Sciences, 2(4), 7-13. Retrieved from www.isca.in/IJMS/Archive/v2i4/2.ISCA-RJMS-2013-022.pdf

7. Austen, S., Seymour, R., Brown, K., Furneaux, C., \& McCabe, A. (2008). Multi-Outcome Construction Policies: Literature Review on Stakeholder Theory. Research Report No: 2006-036-A-05. CRC for Construction Innovation, Brisbane.

8. Ayegba, C. (2013). An Assessment of Material Management on Building Construction Sites.

9. Civil and Environmental Research, 3(5), 18-22. Retrieved from 
10. http://www.iiste.org/Journals/index.php/CER/article/viewFile/5481/5 581

11. Bell, J. (2005). Doing Your Research Project: A Guide for First-Time Researchers in Education, Health and Social Science (4th ed.). London: Open University Press.

12. Bhattacherjee, A. (2012). Social Science Research: Principles, Methods, and Practices ( $1^{\text {st }}$ ed.). Tampa Bay: Scholar Commons, University of South Florida.

13. Bryman, A. (2006). Integrating Quantitative and Qualitative Research: How is it Done?

14. Qualitative Research, 6(1), 97-113. Retrieved from

15. http://qrj.sagepub.com/content/6/1/97

16. Bryman, A. (2012). Social Research Methods (4th ed.). Oxford: Oxford University Press.

17. Chinyio, E., \& Olomolaiye, P. (2010). Construction Stakeholder Management. Oxford: Blackwell Publishing Ltd.

18. Chudley, R., \& Greeno, R. (2008). Building Construction Handbook (7th ed.). Oxford: Elsevier Ltd.

19. Creswell, J. W. (2012). Educational Research: Planning, Conducting and Evaluating Quantitative and Qualitative Research (4th ed.). Boston: Pearson Education, Inc.

20. Gachanja, J. (2015). Mitigating Road Traffic Congestion in the Nairobi Metropolitan Region.

21. KIPPRA Policy Brief No. 2/2015. The Kenya Institute for Public Policy Research and Analysis.

22. Hannure, N. K., \& Kulkarni, S. S. (2014). Comparative Study of Traditional Material

23. Management and Material Management with ICT Application. Current Trends in Technology and Science, 3(4), 301-307. doi: 10.13140/2.1.1279.8082

24. Jha, K. N., \& Iyer, K. C. (2006). Critical Factors Affecting Quality Performance in Construction Projects. Total Quality Management, 17(9), 1155-1170. doi: 10.1080/14783360600750444.

25. Joy, P. K. (1991). Handbook of Construction Management (2nd ed.). Delhi: Macmillan India Limited.

26. Kairu, K. M. (2015). Role of Strategic Inventory Management on Performance of Manufacturing Firms in Kenya: A Case of Diversey Eastern and Central Africa Limited. International Academic Journal of Procurement and Supply Chain Management, 1(4), 22-44. Retrieved from

27. http://www.iajournals.org/articles/iajpscm_v1_i4_22_44.pdf 
28. Kasim, N. (2011). ICT Implementation for Materials Management in Construction Projects: Case Studies. KICEM Journal of Construction Engineering and Project Management, 1(1), 31-36. Retrieved from http://www.koreascience.or.kr/article/ArticleFullRecord.jsp?cn=E1G AAO_2011_v1n1_31

29. Kasim, N. B., \& Ern, P. A. S. (2010). The Awareness of ICT Implementation for Materials Management in Construction Projects. International Journal of Computer and Communication Technology, 2(1), 1-10. Retrieved from www.interscience.in/IJCCT_Vol2_No1/IJCCTVol2_No1_Paper1.pdf

30. Keitany, P. J., Wanyoike, D. M., \& Richu, S. (2014). Assessment of the Role of Materials Management on Organizational Performance: A Case of New Kenya Cooperative Creameries Limited, Eldoret Kenya. European Journal of Materials Sciences, 1(1), 1-10. Retrieved from http://www.eajournals.org/wp-content/uploads/Assessment-of-theRole-of-Materials-Management-on-Organizational-Performance-.pdf

31. Keng, T. C. (2011). Study of Quality Management in Construction Projects. Chinese Business Review, 10(7), 542-552. Retrieved from http://irep.iium.edu.my/2298/1/StudyofQualityManagementinConstru ctionProjects\%5B1\%5D.pdf

32. Kinyanjui, J. N. (2014). Influence of Contextual and Cognitive Factors on the Relationship Between Performance Contracting System and Organizational Performance in Government Ministries in Kenya (PhD Thesis). University of Nairobi.

33. Kitheka, S. S., \& Ondiek, G. O. (2014). Inventory Management Automation and the Performance of Supermarkets in Western Kenya. International Journal of Research in Management \& Business Studies, 1(4), 9-18. Retrieved from http://ijrmbs.com/vol1issue4/kitheka_s.pdf

34. Kohilambal, E., Kothai, P. S., \& Priya, M. M. (2016). Evaluation of Material Procurement Process in Construction Industry. International Journal of Recent Trends in Engineering \& Research, 2(3), 273-276. Retrieved from

35. http://www.ijrter.com/papers/volume-2/issue-3/evaluation-ofmaterial-procurement-process-in-construction-industry.pdf

36. Kombo, D. K. \& Tromp, D. L. A. (2006). Proposal and Thesis Writing: An Introduction (1st ed.). Nairobi: Paulines Publications Africa.

37. Koskela, L., \& Howell, G. (2002). The Underlying Theory of Project Management is Obsolete. Paper presented at PMI Research Conference. 
http://usir.salford.ac.uk/9400/1/2002_The_underlying_theory_of_pro ject_management_is_obsolete.pdf

38. Kothari, C. R. (2004). Research Methodology: Methods and Techniques (2nd ed.). New Delhi: New Age International (P) Ltd.

39. Krejcie, R. V., \& Morgan, D. W. (1970). Determining Sample Size for Research Activities.

40. Educational and Psychological Measurement, 30(1), 607-610. Retrieved from

41. http://home.kku.ac.th/sompong/guest_speaker/KrejcieandMorgan_art icle.pdf

42. Kumar, K. S., \& Vikranth, J. (2012). A Study on Resource Planning in Highway Construction Projects. International Journal of Engineering Research and Applications, 2(4), 1960-1967. Retrieved from http://www.ijera.com/pages/v2no4.html

43. Lenin, P., Krishmaraj, L., Prasad, D. N., \& Kumar, V. R. P. (2014). Analysis of Improper Material Management Affecting Cost in Construction Projects. International Journal for Research in Applied Science and Engineering Technology, 2(5), 486-492. Retrieved from http://www.ijraset.com/fileserve.php?FID=507

44. Madhavi, T. P., Mathew, S. V., \& Sasidharan, R. (2013). Material Management in Construction: A Case Study. International Journal of Research in Engineering and Technology, 2(1), 400-403. Retrieved from http://esatjournals.net/ijret/2013v02/i13/IJRET20130213075.pdf

45. Manavazhi, M. R., \& Adhikari, D. K. (2002). Material and Equipment Procurement Delays in Highway Projects in Nepal. International Journal of Project Management, 20(1), 627-632. Retrieved from http://s3.amazonaws.com/zanran_storage/mucc.mahidol.ac.th/Conten tPages/47102425.pdf

46. Mane, P. P., \& Patil, J. R. (2015). Quality Management System at Construction Projects.

47. International Journal of Engineering Research and Applications, 5(3), 126-130. $\quad$ Retrieved from http://www.ijera.com/papers/Vol5_issue3/Part\%20\%203/W50303126130.pdf

48. Migiro, S. O., \& Magangi, B. A. (2011). Mixed Methods: A Review of Literature and the Future of the New Research Paradigm. African Journal of Business Management, 5(10), 3757-3764. doi: 10.5897/AJBM09.082. 
49. Mugenda, O. M., \& Mugenda, A. G. (2003). Research Methods: Quantitative and Qualitative Approaches (1st ed.). Nairobi: Acts Press.

50. Muhwezi, L., Chamuriho, L. M., \& Lema, N. M. (2012). An Investigation into Materials Wastes on Building Construction Projects in Kampala, Uganda. Scholarly Journal of Engineering Research, 1(1), 11-18. Retrieved from http://www.academia.edu/5084340/An_investigation_into_Materials _Wastes_on_Building_Construction_Projects_in_Kampala-Uganda

51. Nachmias, C. F., \& Nachmias, D. (2005). Research Methods in the Social Sciences (5th ed.). London: Hodder Arnold.

52. Ogbo, A. I., Onekanma, I. V., \& Ukpere, W. I. (2014). The Impact of Effective Inventory Control Management on Organisational Performance: A Study of 7 Up Bottling Company Nile Mile Enugu, Nigeria. Mediterranean Journal of Social Sciences, 5(10), 109-118. doi: 10.5901/mjss.2014.v5n10p109.

53. Patel, K. V., \& Vyas, C. M. (2011). Construction Materials Management on Project Sites.

54. Paper presented at the National Conference on Recent Trends in Engineering and Technology. Retrieved from http://www.scribd.com/doc/137886194/CONSTRUCTION-

MATERIAL-MANAGEMENT-ON-PROJECT-SITES\#scribd

55. Patil, A. R., \& Pataskar, S. (2015). Material Management Techniques on Construction Project. International Journal of Advance Foundation and Research in Science and Engineering, 1(1), 67-72. Retrieved from http://www.ijafrse.org/Volume2/tace/10.pdf

56. Phillips, R., Freeman, R. E., \& Wicks, A. C. (2003). What Stakeholder Theory is Not.

57. Business Ethics Quarterly, 13(4), 479-502. Retrieved from http://scholarship.richmond.edu/cgi/viewcontent.cgi?article=1016\&c ontext=management-faculty-publications

58. Phu, N. L., \& Cho, A. M. (2014). Factors Affecting Material Management in Building Construction Projects. International Journal of Scientific Engineering and Technology Research, 3(1), 2133-2137. Retrieved from http://ijsetr.com/uploads/321654IJSETR1269-365.pdf

59. Radosavljevic, M., \& Bennett, J. (2012). Construction Management Strategies: A Theory of Construction Management. London: WileyBlackwell.

60. Ritz, G. J. (1994). Total Construction Project Management. Boston: Mcgraw-Hill Inc. 
61. Rubin, H. J., \& Rubin, I. S. (2005). Qualitative Interviewing: The Art of Hearing Data (2nd ed.). London: Sage Publications Ltd.

62. Saunders, M., Lewis, P., \& Thornhill, A. (2009). Research Methods for Business Students (5th ed.). London: Pearson Education Limited

63. Sekaran, U. (2003). Research Methods for Business: A Skill-Building Approach. New York: John Wiley \& Sons.

64. Sindhu, S., Nirmalkumar, K., \& Krishnamoorthy, V. (2014). Performance Analysis of Inventory Management System in Construction Industries in India. International Journal of Innovative Research in Science, Engineering and Technology, 3(4), 1148811493.

Retrieved

from http://www.ijirset.com/upload/2014/april/84_Performance.pdf

65. Somekh, B., \& Lewin, C. (Eds.) (2008). Research Methods in the Social Sciences (1st ed.). New Delhi: Sage Publications India Pvt Ltd.

66. Song, J., Haas, C. T., \& Caldas, C. H. (2006). Tracking the Location of Materials on Construction Job Sites. Journal of Construction Engineering and Management, 132(9), 911-918. doi: 10.1061/(ASCE)0733-9364(2006)132:9(911).

67. South African National Roads Agency. (2011). South African Pavement Engineering Manual: Materials Testing. South African National Roads Agency Ltd.

68. Takim, R., (2009). The Management of Stakeholders' Needs and Expectations in the Development of Construction Project in Malaysia. Modern Applied Science, 3(5), 167-175. Retrieved from http://web.nchu.edu.tw/pweb/users/arborfish/lesson/8490.pdf

69. Tanzania National Roads Agency (TANROADS). (2003). Field Testing Manual. Ministry of Works. The United Republic of Tanzania.

70. Transport Research Laboratory (TRL). (1999). Guidelines on the Selection and Use of Road Construction Materials. Department for International Development (DFID).

71. Wambugu, L. N., Kyalo, N. D., Mbii, M., Nyonje, R. O. (2015). Research Methods: Theory and Practice. Nairobi: Aura Publishers

72. Yin, R. K. (2009). Case Study Research: Design and Methods (4th ed.). London: Sage Publications, Inc.

73. Zeb, A., Malik, S., Nauman, S., Hanif, H., \& Amin, O. S. (2015). Factors Affecting Material Procurement, Supply and Management in Building Projects of Pakistan: A Contractor's Perspective. Paper presented at the International Conference on Innovations in Civil and Structural Engineering held in Istanbul, Turkey. Retrieved from http:/urst.org/siteadmin/upload/2209U0615309.pdf 